\title{
IMPLEMENTASI MANAJEMEN BERBASIS SEKOLAH (STUDI DI SMP ISLAM AL-AZHAR 37 PEKANBARU)
}

\author{
Rini Setyaningsih $^{\left.a^{*}\right)}$, Aisyah Nurhuda Suci ${ }^{a}$, Feni Adriani Puspasari ${ }^{a)}$ \\ ${ }^{a)}$ UIN Sultan Syarif Kasim Riau, Indonesia \\ *)e-mail korespondensi: rinisetyaningsih28@gmail.com
}

Riwayat artikel : diterima: 06 November 2020; direvisi: 16 November 2020; disetujui: 06 Desember 2020

\begin{abstract}
Abstrak. Manajemen Berbasis Sekolah (MBS) adalah penyerasian sumberdaya yang dilakukan secara mandiri oleh sekolah dengan melibatkan semua kelompok pemangku kepentingan. MBS juga memberikan keluasaan bagi sekolah untuk menentukan arah dan kebijakan yang relevan dengan situasi dan kondisi lingkunganya. Tujuan dari penelitian ini adalah untuk mengetahui bagaimana implementasi MBS di Sekolah Menengah Pertama yang Berbasis Keislaman, dalam hal ini penulis memilih lokasi di SMP Islam Al- Azhar 37 Pekanbaru. Metode penelitian yang penulis gunakan dalam kajian ini adalah penelitian kualitatif dengan pendekatan studi kasus. Subjek penelitian adalah Kepala Sekolah, Wakil Kesiswaan, Wakil Humas, Tenaga Tata Usaha, dan 2 orang guru serta 5 orang siswa. Objek penelitian adalah implementasi manajemen berbasis sekolah. Teknik pengumpulan data yang digunakan adalah observasi, wawancara dan dokumentasi. Hasil dari penelitian ini penulis menemukan beberapa kebijakan sekolah yang berhubungan dengan manajemen peserta didik, manajemen hubungan sekolah dengan masyarakat, manajemen kurikulum, manajemen personal, manajemen layanan khusus, manajemen sarana dan prasarana, manajemen anggaran sekolah. Salah satu kebijakan terkait manajemen peserta didik yaitu registrasi calon siswa baru secara online dan calon siswa harus memenuhi syarat dan ketentuan yang sudah diberikan sekolah. Kemudian, bagi yang memenuhi syarat akan melakukan tes wawancara, matematika, bahasa inggris, mengaji dan hafalan juz 30.
\end{abstract}

Kata Kunci: implementasi; manajemen; sekolah

\section{IMPLEMENTATION OF SCHOOL BASED MANAGEMENT (Studi at Al-Azhar 37 Middle School in Pekanbaru)}

\begin{abstract}
School Based Management (SBM) is the alignment of resources which independently ran by schools where all stakeholder groups involved. SBM also provides a flexibility for schools to determine directions and policies that are relevant to the situation and environmental conditions. The purpose of this study was to determine the implementation of SBM in Islamic-Based Junior High Schools. This research was taken at Al-Azhar 37 Middle School in Pekanbaru. The research method that was qualitative research with a case study approach. The research subjects were the principal, student representatives, public relations representatives, administrative staff, and 2 teachers and 5 students. The research object was the implementation of school-based management it self. The data collection techniques used observation, interviews and documentation. As the results of this study, the authors found that several school policies were related to student management, school relationship management with the community, curriculum management, personal management, special service management, facilities and infrastructure management, school budget management. One of the policies that related to student management was providing the online registration of prospective new students as well as giving prospective students the terms and conditions It was continually completed by the requirements to do an interview, taking test of Math, English, Recitation and memorization test juz 30.
\end{abstract}

Keywords: implementation; management; school

\section{PENDAHULUAN}

Manajemen pendidikan dengan sistem sentralistis tidak memberikan kemajuan dan peningkatan pada kualitas pendidikan Indonesia. Pada kondisi tertentu sistem sentralistik menyebabkan terjadinya kemandekan kerativitas pada satuan pendidikan. Oleh karena itu perlu dilakukan pembaharuan di bidang pendidikan. Lahirnya era otonomi daerah menjadi gerbang untuk merealisasikan reorientasi paradigma pendidikan dari sistem sentralistis menuju sistem desentralistis pada manajemen pendidikan. Dengan dikeluarkannya kebijakan mengenai otonomi pendidikan melalui strategi penerapan Manajemen Berbasis Sekolah (MBS) menjadikan kesempatan tersebut menjadi tampak nyata.

\section{Manajemen Berbasis Sekolah}

Manajemen Berbasis Sekolah menurut Depdiknas ialah model manajemen yang memberikan otonomi yang lebih besar kepada sekolah dan mendorong pengambilan keputusan pasrtisipatif yang melibatkan secara langsung stakeholder sekolah (guru, siswa, kepala sekolah, orang tua dan masyarakat) dalam meningkatkan mutu sekolah berdasarkan kebijakan pendidikan nasional. Manajemen Berbasis Sekolah mengangkat tema desentralisasi yang merupakan pengalihan tanggung jawab dari pemerintah pusat kepada pemerintah daerah dalam hal perencanaan, manajemen, penggalian dana 
dan alokasi sumber daya. MBS ini hakikatnya tidak hanya sekedar pengalihan sentral dari sistem sentralitik menuju desentralistik melainkan diharapkan adanya kemandirian sekolah dalam membangun sekolah yang efektif. (Jalal \& Supriadi, 2001, p. 122) Pemberian otonomi yang lebih besar, menjadikan sekolah memiliki kewenangan yang lebih luas dalam mengelola lembaga sekolahnya sehingga dengan ini diharapkan sekolah lebih mandiri. Hal ini juga sejalan dengan pendapat Miarso yang menyebutkan bahwa pengertian pengelolaan berbasis sekolah merupakan pelimpahan wewenang kepada pihak sekolah untuk mengambil keputusan mengenai alokasi dan pemanfaatan sumber-sumber berdasarkan aturan akuntabilitas yang berkaitan dengan sumber tersebut.Kebijakan manajemen berbasis sekolah ini dilandasi oleh asumsi bahwa dengan adanya pelimpahan kewenangan dan tanggung jawab yang lebih luwes kepada sekolah dan anggaran dana yang lebih besar sebagai bentuk tunjangan dalam merealisasikan tujuan kebijakan yang sesuai dengan serangkaian garis pedoman kebijakan yang lebih tegas dan meletakkan strategi manajemen prestasi yang terartikulasi di atas perencanaan tersebut maka akan memudahkan dan mendorong peningkatan efektifitas dan efisiensi pendidikan publik. (Siahaan \& dkk, 2006, p. 5)

Bagaimana kinerja sistem pendidikan yang ada di suatu Negara merupakan latar belakang yang melekat dari munculnya Manajemen Berbasis Sekolah. Berbagai inovasi dalam rangka meningkatkan kualitas pendidikan yang difokuskan kepada lingkup kelas seperti pengenalan kurikulum baru, metode pengajaran baru, profesionalisme guru, dan juga sistem evaluasi terus dilakukan diantara tahun 1960 sampai 1970-an, namun sayangnya belum memberikan hasil yang memuaskan. Hal ini terjadi diberbagai Negara seperti Kanada, Amerika, Perancis, Inggris, Selandia baru dan juga Indonesia sendiri. Pada tahun 1980-an terjadi perkembangan yang menggembirakan yaitu keberhasilan pengaplikasian manajemen modern di bidang indsutri dan organisasi komersial. Keberhasilan inilah yang menjadi angin segar di dunia pendidikan. Manajemen modern kemudian diadopsi untuk diaplikasan di dunia pendidikan. Semenjak itulah timbul kesadaran bahwa untuk meningkatkan kualitas pendidikan perlu melakukan terobosan baru yang tidak lagi hanya berada pada lingkup pengajaran di kelas tetapi melompat keluar ke lingkup organisasi sekolah.

Di Indonesia sendiri kesadaran mengenai MBS ini mengalami keterlambatan dari para pengambil kebijakan pendidikan, ketika negara lain sudah mulai melakukan gerakan reformasi model MBS ini pada tahun 1970-in sedangkan di Indonesia baru mucul pada tahun 1999 semenjak diberlakukannya undang-undang tentang otonomi daerah. Hal ini disebabkan oleh system otoriter di Indonesia yang berlaku selama orde baru dimana semua tatanan pendidikan diatur oleh pusat. Sebelumnya. Berbagai upaya telah dilakukan pemerintah untuk meningkatka kualitas pendidikan melalui berbagai program namun karena manajemnnya yang terpusat dan kaku sehingga tidak berjalan efektif. Kemudian timbullah kesadaran untuk memberi kebijakan pengelolaan pendidikan kepada masing-masing sekolah dan lahirlah pemikiran mengenai MBS.

\section{METODE PENELITIAN}

Penelitian menggunakan jenis penelitian kualitatif dengan pendekatan studi kasus. Tempat penelitian adalah di SMP Islam Al-Azhar 37 Pekanbaru. Subjek penelitian adalah Kepala Sekolah (H. Achmad Aprivan, S. Pd), Wakil Kesiswaan (Erma Sunardi, S. Pd), Wakil Humas (Fitri Eka Dinanti, S. Pd), Tenaga Tata Usaha (Nur Farita, S. P), dan 2 orang guru yaitu guru Bahasa Inggris (Jenny Fransisca, M. Pd) dan guru Matematika (Insan Valention Wibawanto, S. Pd., Gr) dan 5 orang siswa. Objek penelitian adalah implementasi manajemen berbasis sekolah. Teknik pengumpulan data yang digunakan adalah observasi, wawancara dan dokumentasi. Deskriptif kualitatif merupakan teknik analaisis data yang memanfaatkan data kualitatif sebagai keabsahan data dan dijabarkan secara deskriptif menggunakan triangulasi sumber.

\section{HASIL DAN PEMBAHASAN}

\section{Manajemen Berbasis Sekolah}

Manajemen Berbasis Sekolah adalah sebuah strategi untuk mewujudkan sekolah yang efektif, efisien, dan produktif. Model manajemen ini ditujukan untuk memberikan kemandirian kepada sekolah serta meningkatkan mutu pendidikan berdasarkan kebijakan pendidikan nasional.(Machali \& Hidayat, 2018, p. 57) Dengan diterapkannya kebijakan desentralisasi dan otonomi daerah, maka diadakan Manajemen Berbasis Sekolah (MBS) yang merupakan sebagai salah satu tuntutan hasil kebijakan tersebut. Menurut Undang-Undang Nomor 32 Tahun 2004 tentang Pemerintah Derah dan Nomor 33 Tahun 2004 tentang Perimbangan Keuangan Pusat dan Daerah telah banyak memberikan kemajuan dan perubahan di berbagai bidang kehidupan dan juga berpengaruh dalam bidang penyelenggaraan pendidikan. Undang-Undang diatas memberikan kewenangan dan keluwesan kepada pemerintah kabupaten/kota terhadap penyelenggaraan yang meliputi seluruh bidang kehidupan dan pendidikan. Kewenangan tersebut melahirkan suatu kebijakan yang dinamakan desentralisasi dan otonomi, dimana kewenangan yang dimiliki pemerintah daerah tersebut digunakan untuk mengatur keseluruhan aspek terkait daerahnya sendiri dengan tetap menjadikan pemerintah pusat sebagai central og government. Oleh karena itu Manajemen Berbasis Sekolah (MBS) atau Mmanajemen Berbasis Madrasah (MBM) merupakan sebuah pespektif baru dalam pengelolaan pendidikan dari desentralisasi pemerintahan.(Machali \& Hidayat, 2018, p. 58). Manajemen Berbasis Sekolah (MBS) secara konseptual merupakan sebuah model pengelolaan yang dapat memberikan suatu kewenangan dan tanggung jawab yang lebih besar terhadap sekolah/madrasah, yaitu dengan memberikan fleksibilitas kepada 
sekolah/madrasah serta dapat mendorong timbulnya partisipasi dari warga sekolah dan masyarakat sekitar.(Depdiknas, 2007, p. 12)

Pengimplementasian dari konsep Manajemen Berbasis Sekolah (MBS) ini adalah sekolah/madrasah mempunyai tanggung jawab yang penuh untuk melaksanakan tugasnya yang berkaitan dengan masalah keuangan, administrasi, dan fungsi setiap masing-masing personil yang ada di sekolah atau madrasah dalam arah dan kebijakan yang telah dirumuskan bersama antara pemerintah dengan orang tua dan masyarakat, skala prioritas yang diatur sekolah/madrasah harus menciptakan kondisi lingkungan kerja yang kondusif dan lebih professional bagi guru, serta dapat membantu masyarakat luas dalam meningkatkan pengetahuan, kemampuan dan keyakinan mereka tentang sekolah/pendidikan.(Machali \& Hidayat, 2018, p. 59)

\section{Tujuan Manajemen Berbasis Sekolah}

Manajemen Berbasis Sekolah sebagai model penerapan pengelolaan satuan pendidikan bertujuan untuk meningkatkan mutu, efisiensi dan pemerataan bagi pendidikan di Indonesia. Untuk meningkatkan mutu dapat dilakukan melalui partisipasi orang tua murid terhadap penyelenggaraan kegiatan di sekolah dan kelas, adanya peningkatan profesionalisme yang dialami guru dan kepala sekolah, pengelolaan sekolah dan kelas yang fleksibilitas serta diberlakukannya system intensif dan disentensif. Kemudian untuk meningkatakan efisiensi dapat diperoleh dari keleluasaan yang didapatkan sekolah/madrasah untuk mengelola segala sumber daya yang dimiliki, partisipasi dari masyarakat dan dari penyederhanaan birokrasi. Sedangkan untuk meningkatkan pemerataan dapat diperoleh melalui tingkat partisipasi masyarakat yang tinggi sehingga dapat memungkinkan pemerintah lebih focus kepada kelompok tertentu. Hal ini dapat menjamin pendidikan dikarenakan rasa kepemilikan tinggi yang tumbuh pada sebagian masyarakat terhadap sekolah/madrasah.(Machali \& Hidayat, 2018, pp. 60-61) Selain itu MBS juga bertujuan untuk melatih sekolah agar dapat mandiri serta dapat memberdayakan sumber daya yang dimiliki melalui otonomi (kewenangan) yang diberikan kepada sekolah supaya mendorong sekolah kearah pengambilan keputusan yang partisipatif. Secara rinci, tujuan MBS dapat diuraikan sebagi berikut:

1. Meningkatkan mutu pendidikan dalam mengelola sumber daya yang ada melalui inisiatif dan kemandirian sekolah.

2. Meningkatkan respons kepedulian warga sekolah serta masyarakat melalui kegiatan pengambilan keputusan yang dilakukan secara bersama dalam upaya penyelenggaraan pendidikan.

3. Meningkatkan rasa tanggung jawab sekolah terkait mutu sekolah kepada orang tua, masyarakat, dan pemerintah.

4. Memicu antar sekolah dalam berkopetensi yang sehat dalam meningkatkan mutu pendidikan yang akan dicapai.(Anonim, 2010).

\section{Prinsip Manajemen Berbasis Sekolah}

Dalam Manajemen Berbasis Sekolah terdapat 4 (empat) prinsip yang merupakan bentuk dari implementasi otonomi daerah khususnya bidang pendidikan yang dijadikan sebagai landasan dalam mengkaji konsep manajemen peningkatan mutu berbasis sekolah yang tentunya sesuai dengan kaidah dan tujuannya, diantaranya yaitu:

1. Otonomi.

Pada prinsipnya, pengelolaan mandiri yang dilakukan oleh sekolah dapat dibedakan dari sudut pandang yang mengasumsikan sekolah hanya sebagai pelaksana satuan organisasi yang hanya melakukan segala sesuatunya dengan berpedoman pada pengarahan pemberian petunjuk yang datang dari atas atau dari luar. Kemandirian merupakan tolak ukur utama dalam menjalankan program dan pendanaan sekolah.

2. Ffleksibilitas.

Dalam arti luas pendidikan, fleksibilitas adalah sebuah keluwesan yang dimiliki sekolah agar dapat mengelola dan memberdayakan sumber daya yang ada seoptimal mungkin dalam rangka meningkatkan mutu sekolah. Sehingga dengan adanya keluwesan yang lebih besar, maka sekolah akan lebih leluasa memanfaatkan sumberdaya tanpa harus menunggu arahan dari atasannya.

3. Partisipasi.

Partisipasi merupakan sebuah respon dalam penciptaan lingkungan yang terbuka dan demokratis. Keikutsertaan antara warga sekolah dan masyarakat didorong untuk mampu terlibat secaralangsung dalam rangka mengupayakan penyelenggaraan pendidikan, dapat dilakukan dari pengambilan keputusan, pelaksanaan dan evaluasi pendidikan dengan harapan mampu meningkatkan mutu pendidikan. Hal ini dilatarbelakangi oleh keyakinan bahwa apabila seseorang berpartisipasi/dilibatkan dalam aspek penyelenggaraan pendidikan maka dapat timbul harapan untuk terus meningkatkan mutu pendidikan.

4. Inisiatif.

Manusia sebagai sumber dinamis merupakan konsep yang didasarkan pada inisiatif. Oleh karena itu, berbagai potensi sumber daya yang dimiliki manusia harus terus digali dan dikembangkan secara terus menerus. Sehingga manusia diperlakukan sebagai salah satu asset yang sangat penting dan dibutuhkan serta mempunyai keunggulan dalam berbagai kompetensi yang harus dikembangkan. (Machali \& Hidayat, 2018, pp. 60-61) 


\section{Karakteristik Manajemen Berbasis Sekolah}

Pada hakikatnya, MBS adalah usaha penyerasian terhadap sumber daya sekolah yang dilakukan secara mandiri yang dimana para kelompok kepentingan (stakeholders) turut serta dilibatkan dalam urusan yang terkait dengan sekolah secara langsung agar dapat mencapai tujuan nasional pendidikan yang meliputu kegiatan pengambilan keputusan dalam rangka mencukupi kebutuhan dalam peningkatan mutu sekolah. Manajemen Berbasisi Sekolah difokuskan kepada manajemen berbasis lokasi, sehingga MBS akan menyediakan berbagai layanan bidang pendidikan yang harus bersifat komprehensif dan cepat tanggap terhadap sekolah itu berada dengan diiringi berbagai kebutuhan masyarakat diwilayah tersebut. Oleh karena itu, bentuk alternative sekolah yang akan dikembangkan dalam kerangka manajemen berbasis sekolah dalam desentralisasi pendidikan ditandai dengan otonomi yang luas di sekolah serta mendapatkan respon partisipasi yang tinggi dari masyarakat yang berhubungan dalam seputar kerangka kebijakan pendidikan nasional.(Pasaribu, 2017, pp. 23-24)

Berikut ini merupakan ciri-ciri sekolah yang menerapkan Manajemen Berbasis Sekolah (MBS), yaitu:

1. Adanya upaya untuk mendukung kinerja sekolah dalam meningkatkan peran serta antara komite sekolah, masyarakat, dan DUDI (Dunia Usaha dan Dunia Industri).

2. Program sekolah yang disusun dengan memprioritaskan kepentingan kurikulum yaitu proses belajar mengajar dan bukan hanya disusun dan dilaksanakan untuk keperluan administratif saja.

3. Terdapat prinsip efektivitas dan efisiensi yang diterapkan dalam pengelolaan sumber daya yang dimiliki sekolah, meliputi anggaran, personil dan fasilitas yang ada.

4. Proses pengambilan keputusan yang disesuaikan dengan kebutuhan, kemampuan dan keadaan lingkungan sekolah serta mampu mengalokasikannya.

5. Mampu menjamin bahwa sekolah terpelihara dengan baik yang dapat dipertanggungjawabkan kepada masyarakat.

6. Melakukan peningkatan profesionalisme antar personil yang ada di sekolah.

7. Sekolah yang meningkatkan kemandiriannya diberbagai bidang.

8. Terlibatnya segala aspek terkait perencanaan dalam program sekolah.

9. Menerapkan system keterbukaan dalam kegiatan pengelolaan pendidikan di sekolah.

Temuan hasil penelitian yang dilakukan dengan cara observasi, wawancara dan dokumentasi kepada narasumber di SMP Islam Al-Azhar dapat diuraikan sebagai berikut:

\section{a. Manajemen Peserta Didik}

Narasumber yang penulis wawancarai pada pembahasan ini yaitu waka bagian kesiswaan, Bapak Erma Sunardi, S.Pd. Beliau menjelaskan sistem penerimaan peserta didik baru di SMP Islam Al-Azhar yaitu dengan membuka registrasi secara online dan calon peserta didik harus memenuhi syarat dan ketentuan yang sudah diberikan sekolah. Kemudian, peserta didik yang memenuhi syarat akan melakukan tes wawancara, matematika, bahasa inggris, mengaji dan hafalan juz 30.

Sekolah menargetkan setiap tahunnya terdapat tiga kelas dengan masing-masing kelas berjumlah 25 murid. Beliau juga menyebutkan rata-rata peserta didik yang mendaftar akan diterima karena sekolah masih dalam tahap pencarian murid dikarenakan baru memasuki tahun ketiga. Hal ini dapat dilihat dari tidak tercapainya target sekolah, dimana pada tahun pertama hanya terdapat satu kelas, pada tahun kedua terdapat dua kelas dan pada tahun ketiga ini sudah hampir mencapai target dengan terdapatnya tiga kelas tetapi jumlah siswa masing-masing kelas masih kurang dari 25 . Untuk sistem zonasi, SMP Islam Al-Azhar belum menerapkannya, hal ini dibuktikan dengan masih diterimanya peserta didik yang dari luar kecamatan tampan. Pada pengelolaan peserta didik, cara sekolah dalam menangani peserta didik yang bermasalah yaitu melalui guru BK, Tanse (Ketahanan Sekolah) dan juga melalui kesiswaan. Kemudian sekolah juga berkolaborasi dengan wali kelas dan guru mata pelajaran tertentu. Bagi peserta didik yang bermasalah seperti melanggar aturan sekolah, maka akan diberi peringatan terlebih dahulu dan kemudian baru diberi sanksi. Sanksi yang diberikan harus bersifat mendidik dan tidak boleh memukul peserta didik, contohnya seperti menghafal, menulis istighfar 100 kali, dan lain sebagainya. Kasus pelanggaran yang sering terjadi di sekolah seperti, tidak memakai sepatu sesuai aturan dan bagi yang perempuan tidak memakai kaos kaki diatas mata kaki. Dalam mengurangi terjadinya pelanggaran tata tertib ini, kesiswaan melakukan upaya penggerakan OSIS, dimana OSIS disini dijadikan contoh atau teladan oleh yang lainnya.

Sejauh ini kendala yang dihadapi sekolah dalam menangani kasus yang terjadi pada peserta didik belum ada karena pihak sekolah selalu berupaya menjalin komunikasi yang baik antar siswa maupun orang tua, hal ini bertujuan agar tidak terjadinya kesalah pahaman antara kedua pihak. Dalam rangka meningkatkan kreatifitas dan pengembangan bakat peserta didik, pihak sekolah menyediakan fasilitas seperti mengadakan kegiatan ekstra kurikuler diantaranya: badminton, memanah, silat, futsal, basket, tari, matras, english club, social club, PMR dan catur. Kegiatan ini diadakan sekali dalam seminggu dengan mendatangkan pelatih dari luar yang ahli dibidangnya, selain itu guru juga dilibatkan sebagai Pembina. Prestasi tertinggi sementara yang pernah dicapai siswa yaitu pada bidang catur di tingkat provinsi dan akan maju ke tingkat nasional. Disamping itu, sekolah juga mengadakan berbagai program tahunan seperti azrucup (Al-Azhar Pekanbaru Cup), bulan bahasa yaitu dengan mengadakan berbagai lomba seperti: cerdas cermat, puisi, pidato kebangsaan, solo vocal dengan tema lagu-lagu nasionalisme, dan pekan muharram 


\section{b. Manajemen Humas}

Pada pembahasan ini penulis berkesempatan mewawancarai bagian Humas SMP Islam Al-Azhar yaitu Ibu Fitri Eka Dinanti S.Pd. Beliau menjelaskan hubungan sekolah dengan masyarakat terjalin sangat baik, salah satu contohnya masyarakat menyambut dengan baik kegiatan tahunan yang diadakan sekolah dan ikut terlibat daalm kegiatan itu. Program khusus yang diadakan sekolah dalam rangka menjalin hubungan baik dengan masyarakat yaitu penyumbangan Al-Quran kepada masjid disekitar sekolah, melaksanakan Qurban pada hari raya Idul Adha dan membagikannya kepada masyarakat sekitar, dan juga mengizinkan masyarakat menggunakan fasilitas sekolah untuk kegiatan positif. Dalam meningkatkan popularitas sekolah, sekolah melakukan promosi melalui media sosial seperti instagram, facebook, blog dan sebagainya. Dan juga melalui event-event yang dilaksanakan sekolah seperti AZRUCUP yang diadakan setiap bulan Oktober yang telah diikuti oleh berbagai sekolah baik di dalam maupun diluar pekanbaru. Pihak sekolah melakukan hubungan kerjasama dengan perusahan yang bergerak dibidang penyedia jaringan internet, hal ini sehubung dengan kegiatan sekolah yang sudah berbasis digital seperti sarana belajar peserta didik yang menggunakan Ipad, penginputan nilai dan lain sebagainya.

\section{c. Manajemen Kurikulum}

SMP Islam Al-Azhar 37 Pekanbaru menggunakan kurikulum 2013 yang dikombinasikan dengan kurikulum Cambridge international. Keunggulan sekolah dalam pengembangan kurikulum ini yaitu dalam implementasinya berbasis digital. Buku-buku yang digunakan berbasis digital dan setiap peserta didik menggunakan ipad sebagai media belajar. Penggunaan ipad ini tentunya dibawah pengawasan guru, guru dapat memonitor apa saja aplikasi yang sedang digunakan peserta didik melalui aplikasi khusus yang ada pada guru.

\section{d. Manajemen Personal}

Jumlah tenaga pendidik dan kependidikan yang ada di SMP Islam Al-Azhar 37 Pekanbaru sebanyak 27 orang. Dimana 1 orang kepala sekolah, 1 orang wakil kepala sekolah, 12 orang guru mata pelajaran dan 1 orang guru BK, 1 orang tata usaha, 1 orang IT support, 1 orang PSB (Pusat Sumber Belajar), 3 orang janitor dan 2 orang security. Dalam pengrekrutan tenaga pendidik di SMP Islam Al-Azhar 37 Pekanbaru, standarisasi yang harus dipenuhi calon tenaga pendidik yaitu minimal lulusan S1 dengan IPK minimal 3,00, bisa membaca Al-Quran dan diharapkan memiliki hafalan minimal 1 Juz, bisa berbahasa Arab dan berbahasa Inggris dengan TOEFL minimal 450. Kemudian calon tenaga pendidik yang memenuhi kriteria mengikuti tes wawancara dan tertulis profesional, tes tertulis bahasa inggris dan tes untuk melihat kemampuan IT . Untuk saat ini, sumber daya manusia yang dibutuhkan sekolah sudah mencukupi tetapi belum maksimal, setiap mata pelajaran sudah diampuh oleh guru yang linear, kecuali pada mata pelajaran prakarya yang masih dilimpahkan pada guru mata pelajaran lain.

\section{e. Manajemen Layanan Khusus}

Layanan khusus yang disediakan sekolah yaitu Bimbingan Konseling, Unit Kesehatan Sekolah dan perpustakaan.

\section{f. Manajemen Sarana dan Prasarana Sekolah}

Sarana dan Prasarana yang terdapat di SMP Islam Al-Azhar 37 Pekanbaru yaitu ruang kelas, masjid, lapangan basket, LCD pada setiap ruang kelas, perpustakaan, laboratorium, UKS, dan kantin. Untuk saat ini ruang BK belum ada ditempatkan secara khusus karena masih dalam tahap pembangunan yang dalam waktu dekat akan selesai. Sarana dan prasarana yang ada belum mencapai target yang salah satu faktor penyebabnya terkendala pada anggaran. Pihak SMP Islam Al-Azhar kesulitan dalam meminta bantuan yayasan pusat mengingat yayasan pusat memiliki banyak sekolah.

\section{g. Manajemen Anggaran}

SMP Islam Al-Azhar 37 Pekanbaru berada dibawah naungan yayasan pesantren AL-Azhar Jakarta. Sumber dana yang diperoleh sekolah berasal dari yayasan, uang pangkal, SPP, dan dana BOS. 20\% dari RAB dianggarkan untuk pembangunan sekolah. dan untuk kegiatan ekstra kurikeuler, Anggaran yang dikeluarkan sekolah untuk honor pelatih sejumlah 100/pertemuan, jam 4.00-5.30 dan untuk Pembina 50/pertemuan.

\section{SIMPULAN}

Manajemen Berbasis Sekolah merupakan sebuah model pengelolaan lembaga sekolah dengan memberikan otonomi lebih besar kepada sekolah dan mendorong partisipasi secara langsung warga sekolah bersama masyarakat untuk mewujudkan kemandirian sekolah dalam meningkatkan mutu sekolah berdasarkan kebijakan pendidikan nasional serta perundang-undangan yang berlaku. Implementasi MBS di SMP Islam Al-Azhar Pekanbaru yang terbilang baru ini sudah cukup baik tetapi belum maksimal. Hal ini dapat dilihat dari pengembangan kurikulum yang dilakukan sekolah dengan mengkombinasikan penggunaan kurikulum 2013 dengan Cambridge, dimana fokus utamanya yaitu berbasis islami dan berbasis digital. Cara sekolah dalam melakukan promosi lembaganya yaitu dengan memanfaatkan perkembangan media sosial dan juga secara manual, dan hal ini berlangsung cukup efektif ditandai dengan adanya peningkatan minat peserta didik untuk melanjutkan pendidikan menengah mereka di SMP Islam Al-Azhar 37 Pekanbaru dari tahun ke tahun.

Disamping itu, juga terdapat kekurangan yang salah satunya pada personalia seperti pada tenaga administrasi yang masih sangat minim yang hanya dibebankan kepada satu orang saja. Sangat diharapkan kepada pihak sekolah untuk melakukan rekrutmen tenaga administrasi mengingat makin meningkatnya jumlah peserta didik setiap tahunnya. Dalam hal pendanaan lembaga sekolah diharapkan agar sekolah tidak hanya mengandalkan dana dari yayasan, dana BOS dan SPP saja 
tetapi sebaiknya bisa diperluas lagi dengan mencari masukan dana ke berbagai pihak instansi agar bisa dimanfaatkan untuk keperluan yang mungkin belum bisa tercapai.

\section{REFERENSI}

Anonim. (2010, Maret). Manajemen Peningkatan Mutu Berbasis Sekolah. Dipetik November 30, 2019, dari Jurnal Manajemen, Bahan Kuliah Manajemen: hhttp://jurnal-sdm.blogspot.com/2010/03/manajemen-peningkatan-mutu-berbasis.html Depdiknas. (2007). Manajemen Berbasis Sekolah. Jakarta: Direktorat Jenderal Manajemen Pendidikan Dasar dan Menengah. Jalal, F., \& Supriadi, D. (2001). Reformasi Pendidikan Dalam Otonomi Daerah. Yogyakarta: Adicita Karya Nusa.

Machali, I., \& Hidayat, A. (2018). The Handbook of Education Management Edisi 2. Yogyakarta: PRENADAMEDIA GROUP. Pasaribu, A. (2017, Maret). Implementasi Manajemen Berbasis Sekolah Dalam Pencapaian Tujuan Pendidikan Nasional di Madrasah. EduTech, 3(1), 23-24.

Siahaan, A., \& dkk. (2006). Manajemen Pendidikan Berbasis Sekolah. Jakarta: Quantum Teaching. 